\title{
PENANAMAN KARAKTER MODERAT DI MA'HAD ALY SITUBONDO
}

\section{NAMING OF MODERATE CHARACTERS AT MA'HAD ALY SITUBONDO}

\author{
Asror Baisuki \\ Ma'had Aly Situbondo
}

\section{Ta'rif}

Puslitbang Pendidikan Agama dan Keagamaan

Jl. MH Thamrin No. 6 Jakarta Pusat

Email : ta75rif@gmail.com

Naskah diterima 10 Oktober 2017, direvisi 15 November 2017, disetujui 20 November 2017

\section{Abstract}

The emergence of religious ideologies amid increasingly complex social conditions is believed to be one of the factors driving social conflict in society. Radicalism and liberalism have their respective roles in tipping the social conflict. These two religious ideologies compete in maintaining the vision and mission in their own respective way, the radical group in its conservative way while the liberal group with modernization. Therefore, it is necessary for the presence of a third group that can reconcile the two previous groups. The conciliatory effort has been started by Ma'had 'Aly Situbondo by instilling moderate character to the santri so as not to lean to the right (radical) and left (liberal). This study aims to examine in depth about the ways of cadres of fiqh experts (Ma'had 'Aly) in instilling a moderate character to the students and to identify the moderate character that has been embedded in the santri. This research shows that the ways Ma'had 'Aly pursued in moderating the moderate character of the santri is a model of integration. The integration in question is integration in the academic field as well as integration in the daily activities of santri. These two models of integration can form a moderate character in the souls of the santri, but the most dominant in the formation of such characters is the use of intensive figh ushul. The use of ushul figh for Ma'had 'Aly is a must that should not be ignored in any legal study.

Keywords: Character, Moderate, Pesantren Learning

\section{Abstrak}

Munculnya ideologi-ideologi keagamaan ditengah kondisi sosial yang semakin kompleks diyakini sebagai salah satu faktor pemicu konflik sosial di tengah masyarakat. Radikalisme dan liberalisme memiliki perannya masing-masing dalam memperuncing konflik sosial tersebut. Dua ideologi keagamaan ini, bersaing dalam mempertahankan visi dan misi dengan caranya sendiri, kelomok radikal dengan caranya yang konservativ sedangkan kelompok liberal dengan modernisasi. Oleh kerena itu, perlu kehadiran kelomok ketiga yang bisa mendamaikan pertikaian dua kelompok terdahulu. Upaya mendamaikan tersebut sudah dimulai oleh Ma'had 'Aly Situbondo dengan cara menanamkan karakter moderat kepada para santri agar tidak condong ke arah kanan (radikal) dan kiri (liberal). Penelitian ini bertujuan untuk menelaah secara mendalam tentang cara-cara lembaga kader ahli figh (Ma'had 'Aly) ini dalam menanamkan karakter moderat terhadap para santri serta juga ingin mengetahui karakter moderat apasajakah yang sudah tertanam pada diri para santri. Melalui penelitian ini, dihasilkan bahwa cara-cara yang ditempuh Ma'had 'Aly dalam menanmkan karakter moderat terhadap para santri adalah model integrasi. Integrasi yang dimaksud adalah integrasi dalam bidang akademik dan juga integrasi dalam kegiatan sehari-hari santri. Dua model integrasi inilah yang dapat membentuk karakter moderat pada jiwa para santri, namun yang paling dominan dalam pembentukan karakter tersebut adalah penggunaan ushul figh secara intensiv. Penggunaan ushul figh bagi Ma'had 'Aly adalah sebuah keharusan yang tidak boleh diacuhkan dalam setiap kajian hukum.

Kata kunci: Karakter, Moderat, Pembelajaran Pesantren 


\section{PENDAHULUAN}

Islam sebagai agama samawi terakhir memiliki banyak ciri khas (khshaish) yang membedakannya dengan agama yang lain. Ciri khas Islam yang paling menonjol adalah tawassuth, ta'adul, dan tawazun. Ini adalah beberapa ungkapan yang memiliki arti sangat berdekatan atau bahkan sama. Oleh karena itu, tiga kata tersebut bisa disatukan menjadi wasathiah. Watak wasathiah Islam ini dinyatakan oleh Allah sendiri dalam alQuran;

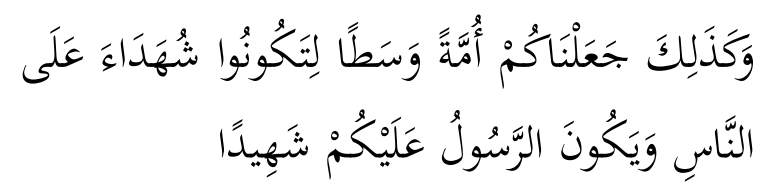

Dan begitu juga kami jadikan kalian umat yang wasath (moderat) agar kalian menjadi saksi (atas perbuatan) manusia dan rosul menjadi saksi bagi kalian. (QS. Al-Baqoroh; 143)

Wasath (moderat) berarti pemaduan yang mungkin dilakukan antara dua hal atau beberapa hal, antara beberapa sisi persoalan atau beberapa sudut pandang yang berbeda. Bila pemaduan tidak mungkin dilakukan, maka diambil jalan tengah yang tidak lebih dekat ke kanan dan tidak lebih dekat ke kiri. Wasath juga berarti keengganan untuk melihat hanya dengan mata satu sehingga yang terlihat hanya satu sisi persoalan saja. (KH. Afifuddin Muhajir)

Agama yang dibawa oleh Nabi Muhhammad ini datang di tengah-tengah bangsa Arab yang saat itu masih teguh pendirian dengan agama nenek moyang mereka yaitu, menyembah berhala. Islam datang dalam rangka mengeluarkan mereka dari kejahiliaan (kebodohan) ini. Orang-orang arab pada saat itu juga masih sangat membanggakan klan masing-masing sehingga hal ini yang sering menyebabkan konflik diantara mereka, maka tidak heran apabila misi Islam yang lain adalah misi perdamaian, dengan misi inilah Nabi Muhammad berusaha menyatukan mereka dalam satu agama yaitu Islam. Sejak awal, Islam diperkenalakan dengan lemah lembut dan kasih sayang, Islam adalah rahmatan litalamin. Dengan begitu bisa difahami bahwa Islam datang dengan semangat menyatukan bukan memecah belah.

Demikian Islam datang dengan segala rahmatnya, namun wajah Islam yang awalnya menampakkan raut damai, saling menghargai, dan saling mengasihi sekarang sudah berubah menjadi suram tampak seakan agama teroris, sadis, dan pemberontak. Ditambah lagi di ujung yang berlawanan, tampaknya Islam sudah mulai diperkenalkan sebagai agama yang sangat menghargai kebebasan, termasuk kebebasan berakidah, kelompok pertama dikenal sebagai kelompok radikal dan yang terakhir disebut kelompok liberal.

Radikalisme dan Liberalisme merupakan dua aliran yang lekat dengan stigma negatif hampir disetiap negara termasuk di Indonesia. Stigma ini bukan tanpa alasan, keberadaan dua aliran tersebut dianggap mengancam ideologi Agama bahkan sebuah Negara. Jika radikal lebih dikenal dengan kelompok yang beraliran keras beda halnya dengan liberal, kelompok yang terakhir ini dikenal dengan ideologinya yang terlalu bebas dan hedonis lebih mengedepankan kesenangan duniawi. ${ }^{1}$

Mengenai ancaman dua aliran tersebut terhadap agama bahkan negara, semua

${ }^{1}$ Achmad Satori Ismail dkk, 2012. Islam Moderat Menebar Islam Rahmatan Lil 'Alamin, Jakarta timur, pustaka ikadi.. hal 44. 
orang pasti menyadarinya, ancaman ini bukan lagi hal yang bisa disembunyikan karena gerakan mereka sudah benarbenar masif dan rapi. Memang cara mereka menyebarkan ancaman-ancaman tidak dengan frontal langsung mengganti tatanan ideologi yang sudah rapi melainkan dengan cara normalisasi ajaran mereka disemua lini, tidak heran jika banyak sekali orang yang tidak sadar bahwa mereka sudah makan umpan atau bahkan sudah terkena kail pancing radikalisme dan liberalisme. Dengan normalisasi seperti ini, alih-alih dilawan malah korbannya akan terasa nyaman dengan umpan yang mereka tebar. Mnurut K.H Lutfi Bashori, salah satu pemikir muda NU, gerakan semacam ini adalah bentuk kekwatiran para musuh Islam di seluruh dunia. ${ }^{2}$

Dua aliran yang sudah dipaparkan di atas, radikalisme dan liberalisme, adalah dua aliran yang saling bertentangan secara ideologi karena radikalisme berada di ujung kanan dan liberalisme berda di ujung kiri. Keberadaan keduanya dianggap berbahaya bagi ideologi agama terutama Islam. Maka dibutuhkan penengah yang bisa melerai pertikaian sekaligus penawar dua aliran ekstrim tersebut, pihak ketiga ini disebut dengan kelompok moderat, banyak kalangan menyebutkan bahwa moderat merupakan sintesa dari dua kelompok yang bertikai di atas, dianggap bertikai karena radikal beragama secara tekstual di satu sisi dan liberal menghendaki beragama secara bebas di sisi lain, namun permasalahannya bagaimana sintesa ini terwujud.

${ }^{2}$ http://www.nugarislurus.com/2015/03/khluthfi-bashori-alwi-10-kiat-menghadapi-jil-jaringanIslam-liberal.html\#axzz3pT5LNdhA
Ma'had 'Aly Sukorejo Situbondo sebagai salah satu lembaga kader ahli figh di Jawa Timur tampil untuk menjadi oase di tengah gurun pemikiran dan perang ideologi yang sedang berkecamuk saat ini. Lembaga ini berupaya mencetak kader-kader cendekiawan muda muslim yang beraliran moderat, dan upaya ini bukanlah isapan jempol belaka. Hal ini bisa terlihat dalam beberapa tulisan yang lahir dari tangantangan santri Ma'had 'Aly, semisal buku Islam Tengah, Fiqh Today, Islam Moderat (karangan Prof.Dr. Abu Yasid - alumni Ma'had 'Aly) Figh Progresif (karya santri Ma'had 'Aly) dan juga buletin Tanwirul Afkar (TA) yang diterbitkan setiap satu bulan satu kali. Dalam buku-buku ini tertuang jelas pikiran-pikiran moderat mereka, sehingga buku-buku tersebut sangat sesuai untuk dikonsumsi ditengah pertikaian Islam kanan dan kiri seperti saat ini.

Dari latar belakang masalah tersebut di atas, maka penelitian ini berusaha menjawab permasalahan sebagai berikut : Bagaimana sistem pembelajaran Ma'had 'Aly Situbondo dalam menumbuhkan karakter moderat? Nilai apa saja yang ditanamakan di Ma'had 'Aly Situbondo dalam menumbuhkan karakter moderat?

Berdasarkan pada rumusan masalah di atas ada beberapa tujuan penelitian yang ingin diperoleh, yaitu; Untuk mendeskripsikan sistem pembelajaran Ma'had 'Aly Situbondo dalam menumbuhkan karakter moderat terhadap para santrisantrinya. Untuk memaparkan sekaligus mengklasifikasikan karakter moderat apa saja yang ditanamkan di Ma'had 'Aly Sukorejo Situbondo. 


\section{Kerangka Konseptual}

\section{Radikalisme}

Secara etimologis, radikalisme berasal dari kata radix, yang berarti akar. Seorang radikal adalah seseorangyang menginginkan perubahan terhadap situasi yang ada dengan menjebol sampai keakar-akarnya. A radical is a person who favors rapid and sweeping changes in laws of goverments (Seorang radikal adalah seorang yang menyukai perubahanperubahan secara cepat dan mendasar dalam hukum dan metode-metode pemerintahan). Jadi radikalisme dapat dipahami sebagai suatu sikap yang mendambakan perubahan dari status quo dengan jalan menghancurkan status quo secara total, dan dengan menggantinya dengan suatu yang baru sama sekali berbeda. Biasanya cara yang digunakan adalah revolusioner artinya menjungkir balikkan nilai-nilai yang ada secara drastis lewat kekerasan (violenceri) dan aksi-aksi ekstrim. ${ }^{3}$

\section{Liberalisme}

Dalam kamus besar bahasa indonesia kata liberal berarti berpandangan bebas. Cahrle Kurzman menilai liberalisme sebagai kosakata yang mengandung makna adanya gagasan yang secara terus menerus dalam memberikan pemahaman atas kitab suci untuk disesuaikan dengan modernitas, rasionalitas, dan tidak menekankan pada segi bahasa literlijk. ${ }^{4}$ Menurut Blinder kaum liberal adalah mereka yang menganut paham perlunya penafsiran secara terus menerus terhada doktrin Islam dan menerjemahkan

\footnotetext{
${ }^{3}$ M. Amin Rais, 1987. Cakrawala Islam, Bandung: Mizan, Cet. 1, hal. 4.

${ }^{4}$ Dr. Zuly Qodir, 2010 . Islam Liberal, Yogyakarta: LkiS, cet I hal 7.
}

bahasa Islam sesuai dengan zamannya ketimbang harus menerimanya secara taken for granted atas kitab suci al-Quran. ${ }^{5}$

Dalam literatur kristaiani, perkataan liberal/liberalisme telah mulai dipakai sejak tahun 1819, tetapi istilah itu baru populer pada zaman Monarki Prancis tengah berkuasa, sekitar tahun 1830. Pada saat itu penyebutan liberalisme menjadi bagian dari kaleidoskop Eropa Kristen. Namun demikian, liberalisme dalam agama Kristen sehingga kahirnya menjadi spirit liberalisme dalam agama baru terjadi pada tahun 1979, tepatnya ketika John Henry Newman menjadi Cardinal. Pada saat itu, liberalisme benar-benar menjadi semangat dalam agama Kristiani. Sejak saat itu pula pemikiran liberal dalam Kristen terus berkembang.

\section{Moderat}

Kata moderat asalnya dari bahasa inggris moderate artinya mengambil sikap tengah: tidak berlebih lebihan pada satu posisi tertentu, ia berada sikap yang tegak lurus dengan kebenaran. Moderator seorang penengah, yang mampu menyatukan dua kubu persoalan secara seimbang dan harmonis, dengan tanpa mengorbankan nilai-nilai kebenaran. Dalam bahasa arab disebut al-wasath. Imam al-Ashfahani mengartikan kata wasath dengan, seimbang tidakterlalukekanan(ifrath) dantidakterlalu ke kiri (tafrith), di dalamnya terkandung makna keadilan, keistiqomahan, kebaikan, keamanan dan kekuatan. ${ }^{6}$

\section{${ }^{5}$ Ibid hal 12.}

${ }^{6}$ Ahmad Satori dkk, 2012. Islam Moderat Menebar Islam Rahmatan Lil 'Alamin, Jakarta: Pustaka Ikadi, cet II hal 43. 


\section{Penanaman Karakter}

Penanaman adalah proses, cara, atau perbuatan menanam, menanami, atau menanamkan ${ }^{7}$. Penanaman yang dimaksud di dalam penelitian ini adalah cara yang dilakukan oleh lembaga dalam menanamkan karakter kepada siswa.

Karakter, secara umum diasosiasikan sebagai temperamen yang memberinya sebuah definisi yang menekankan pada unsur psikososial. Istilah karakter dianggap sama dengan pribadian sebagai ciri atau karakteristik atau sifat khas dari diri seseorang yang bersumber pada bentukanbentukan yang diterima dari lingkungan, misalnya keluarga8.

Stretegi dan Metode Pembelajaran Pendidikan Karakter. Pembelajaran pendidikan karakter secara komprehensif dapat dilakukan dengan menggunakan metode inkulkasi (inculcation), keteladanan (modelling), fasilitasi (fasilitation), dan pengembangan keterampilan (skill building). ${ }^{9}$ Sedangkan penerapan pendidikan karakter dapat dilakukan dengan berbagai strategi pengintegrasian. Strategi yang dapat dilakukan adalah, 1) Pengintegrasian dalam kegiatan sehari-hari, 2) Pengintegrasian dalam kegiatan yang diprogramkan.

Pendekatan Pembelajaran Pendidikan Karakter. Secara teoritis, keberhasilan proses pendidikan karakter antara lain dipengaruhi oleh ketepatan seorang guru dalam memilih

\footnotetext{
${ }^{7}$ Departemen Pendidikan Nasional, Kamus Bahasa Indonesia , (Jakarta: Balai Pustaka, 2007), hal.1135

${ }^{8}$ Doni Koesoema, Pendidikan Karakter, hal. 7980

9 Zubaedi, 2013 Desain Pendidikan Karakter. Jakarta, Kencana Prenada Media Group., hal 231.
}

dan mengaplikasikan pendekatan dalam penanaman nilai-nilai karakter.

Efektivitas proses pendidikan karakter dipengaruhi oleh ketepatan pendekatan yang dipilih guru dalam mengajarkan materi tersebut. Secara teoretis, setidaknya ada delapan pendekatanyang dapat digunakan dalam mengajarkan pendidikan karakter/budi pekerti, yaitu evocation, inculcation, moral reasoning, vlue clarification, value analysis, moral awarnes, commitment approach, dan union approach.

Evocation, pendekatan yang memberikan kesempatan dan keleluasaan pada peserta didik untuk secara bebas mengekspresikan respon afektifnya terhadap stimulus yang diterima. Inculcation, pendekatan agar peserta didik menerima stimulus yang diarahkan agar menuju kondisi siap. Moral reasoning, pendekatan agar terjadi transaksi intelektual taksonomik tinggi dalam mencari pemecahan masalah. Value clarification, pendekatan melalui stimulus terarah agar peserta didik diajak mencari kejelasan isi pesan keharusan moral. Value analysis, pendekatan agar peserta didik dirangsang untuk melakukan analisis nilai moral. Nilai awarnes, pendekatan agar peserta didik menerima stimulus dan dibangkitkan kesadarannya akan nilai tertentu. Commitment approach, pendekatan agar peserta didik sejak awal diajak menyepakati adanya suatu pola pikir dalam proses pendidikan nilai. Union approach, pendekatan agar peserta didik diarahkan untuk melaksanakan secara riil nilai-nilai budi pekerti dalam suatu kehidupan. 


\section{Metode Pembelajaran Pesantren}

Pada dasarnya proses belajar mengajar pada pondok pesantren salafiyah penyelenggara program wajib belajar pendidikan dasar tidak diatur secara rigid. Artinya, selama metode pendidikan dan pegajaran yang sudah berjalan dianggap baik, hal itu dapat terus diberlakukan. Prinsipnya proses belajar mengajr mampu mengantarkan peserta program untuk memahami bahan dan materi pelajaran. Sejalan dengan itu, metode pendidikan tradisional yang menjadi ciri khas pembelajaran pesantren pun dapat digunakan. Metode pembelajaran pesantren dapat dikelompokkan ke dalam empat macam yaitu, wetonan/bandongan, sorogan, hafalan dan halaqoh. ${ }^{10}$

\section{METODOLOGI PENELITIAN}

jenis penelitian ini termasuk jenis penelitian kualitatif dengan berdasarkan pada : data yang muncul berwujud kata - kata dan bukan rangkaian angka. Serta dengan metode penelitian deskriptif artinya melukiskan variabel demi variabel, satu demi satu. Wilayah penelitian yang dijadikan obyek atau sasaran dalam penelitian ini adalah Penanaman Karakter Moderat Di Pesantren; Studi Kasus Terhadap Pembelajaran Pesantren Di Ma'had 'Aly Sukorejo Situbondo. Alasan dipilihnya lembaga ini adalah karena lembaga ini masih memegang tradisi pesantren salaf namun dapat mencetak kader-kader yang berkarakter moderat sehingga menarik untuk diteliti. Sedangkan jenis data dalam penelitian ini dibagi dalam

${ }^{10}$ H. Mahmud, 2006. Model-Model Kegiatan di Pesantren. Ciputat: Media Nusantara,. hal 66. bentuk kata-kata dan tindakan serta sumber data yang tertulis. Sedangkan sumber data dalam penelitian ini, disesuaikan dengan apa yang di konsepsikan oleh Lofland (1984: 47), bahwa sumber data utama dalam penelitian kualitatif ialah kata-kata dan tindakan, selebihnya adalah data tambahan seperti dokumen dan lain-lain. ${ }^{11}$ Data dalam penelitian ini dikumpulkan dengan cara wawancara, observasi dan dokumentasi. Adapun objek yang diwawancara mencakup pimpinan, civitas dan simpatisan Ma'had 'Aly, yaitu: K.H Hariri Abd. Adhim (Mudir Ma'had 'Aly), K.H Afifuddin Muhajir (wakil pengasuh PP.Salafiah Syafi'iah), Prof. Dr. Abu Yasid, Asmuki, M.H.I. Imam Nakhe'i. M.H.I. Selain wawancara tersebut peneliti juga melakukan pengamatan langsung terhadap kegiatan-kegiatan yang berjalan di Ma'had 'Aly, disamping itu penulis juga melakukan dokumentasi terhadap objekobjek yang di anggap penting. Cara-cara yang digunakan penulis dalam menganalisis data hasil penelitian adalah reduksi data, display data dan verifikasi: ${ }^{12}$

\section{HASIL DAN PEMBAHASAN}

\section{Penanaman Karakter Moderat Santri Di Ma'had 'Aly Situbondo}

Karakter moderat yang dimiliki oleh santri Ma'had 'Aly bukanlah hal yang tidak sengaja mereka miliki dan juga bukan keniscayaan dari lembaga ini, akan tetapi melalui proses panjang. Proses penanaman karakter yang diterapkan, menurut para

${ }^{11}$ Lexy J. Moleong, 2002. Metodologi Penelitian Kualitatif, Cet. 13 (Bandung: Remaja Rosdakarya,), hal 122.

${ }^{12}$ Sugiono, 2005. Memhamami Penelitian Kualitatif, Jawa Barat: Alfabeta, hal 92-101 
civitas Ma'had 'Aly melalui cara-cara yang beragam, ini semua dilakukan demi mendapatkan lulusan yang bisa bicara banyak pada era yang sudah semakin global seperti sekarang.

Hal pertama yang harus diselesaikan terlebih dahulu sebelum mengupas proses penanaman karakter moderat di Ma'had 'Aly adalah, apakah moderat itu termasuk karakter ataukah tidak?, pertanyaan ini yang sering digulirkan setiapkali membahas tentang moderat, memang dalam beberapa literatur yang membahas tentang karakter sama sekali tidak dijumpai kata moderat didalamnya. Dalam surat edaran yang dikeluarkan oleh direktur jendral pendidikan dasar, sebagaimana sudah disebutkan dalam baba I, hanya ada sekitar 25 karakter yang harus ditanamakan pada peserta didik dan ternyata moderat tidak masuk pada karakter yang 25 tersebut.

Akan tetepai, meskipun karakter moderat tidak disebutkan secara jelas dalam 25 karakter tersebut, ciri-ciri karakter moderat masih disebutkan didalamnya. Salah satu ciri karakter moderat yang disebutkan dalam 25 karakter tersebut adalah sikap toleransi, cinta damai, cinta tanah air, demokratis, peduli sosial. Sekian karakter ini sebenarnya adalah ciri dari karakter moderat itu sendiri.

Lebih jelas lagi, apa yang dijelaskan dalam buku Islam Moderat Menebar Islam Rahamatan Lil-Alamin yang ditulis oleh Prof. Dr. Achmad Satori Ismail dan kawan-kawan. Dalam buku ini mereka menyebut bahwa moderat adalah karakter. Berangkat dari kenyataan inilah kiranya sudah jelas bahwa moderat juga termasuk ke dalam kategori karakter bangsa yang harus ditanamkan pada semua peserta didik.

Oleh karena itu, Ma'had 'Aly sebagai lembaga excellent di pesantren Salafiah Syafi'iah Sukorejo Situbondo sangat getol dan semangat untuk menanamkan karakter yang menjadi ciri agama Islam ini, moderat. Lebih jauh dari itu, Ma'had 'Aly juga ingin menjadi penawar di tengah-tengah perang pemikiran (ghozwa al-fikri) saat ini yang sama-sama ekstrim, yang satu ekstrim kanan dan yang lain ekstrim kiri.

Ekstrim kanan lebih banyak duhuni oleh mereka yang masih terlalu kaku dalam menyikapi teks-teks agama, pada biasanya mereka memiliki latar belakang pesatren salaf yang menganggap sangat sakral teks kitab kuning, sehingga tidak bisa di otak-atik lagi dan cenderung memahaminya secara rigid. Sedangkan di sisi kiri diisi oleh lulusan barat yang terbiasa dengan lingkungan bebas dan cenderung mentuhankan HAM, dengan mengatasnamakan HAM kadang mereka dengan mudah menabrak otoritas agama yang sudah mapan. Sepertinya HAM hanya ingin dijadikan alat untuk melegitimasi peraktek-peraktek yang menurut mereka benar dan keliru menurut agama.

Di tengah kecamuk dua aliran yang saling bertentangan ini, Ma'had 'Aly ingin mengemuka dengan wajah yang dapat menyatukan dua aliran tersebut, sehingga Ma'had 'Aly bukan kanan dan juga bukan kiri, melainkan sintesa dari dua kelompok ekstrim tersebut. Nama yang cocok bagi penengah diantara dua aliran ekstrim tersebut adalah moderat (wasathiah). Hal ini sesuai dengan difinisi moderat (wasathiah) itu sendiri, bahwa moderat adalah kemampuan memposisikan diri antara 
tafrith (liberal) dan ifrath (radikal), dengan kata lain moderat berarti bukan radikal dan juga bukan liberal. ${ }^{13}$

Wasathiah juga merupakan salah satu karakter Islam, hal ini sebagaimana telah diterangkan oleh Allah dalam al-Qur'an:

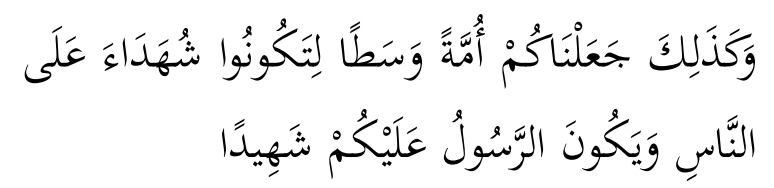

Dan begitu juga kami jadikan kalian umat yang wasath (moderat) agar kalian menajdi saksi (atas perbuatan) manusia dan rosul menjadi saksi bagi kalian. (QS. Al-Baqoroh; 143)

Sebagaimana telah disinggung sebelumnya, bahwa karakter moderat yang dimiliki santri Ma'had 'Aly bukan suatu kebetulan melainkan melaului proses. Dalam paparan data pada bab dua disebutkan bahwa ada empat faktor bagaimana karakter moderat itu bisa dimiliki oleh para santri Ma'had 'Aly. Empat faktor tersebut adalah. Pertama, perpaduan dosennya. Kedua, perpaduan kurikulumnya. Ketiga, perpaduan model pembelajrannya, dan Keempat, perpaduan kegiatannya.

Perpaduan dosen, faktor ini adalah salah satu faktor yang sangat berpengaruh terhadap karakter yang dimiliki oleh para santri. Dosen-dosen yang mengajar di Ma'had 'Aly secara garis besar memiliki dua latar belakang yang berbeda, yaitu latar belakang pesantren murni di satu sisi dan ada yang latar belakang akademisi di sisi yang lain. Dari perpaduan dosen ini santri bisa belajar bagaimana menghargai turats (warisan Ulama' terdahulu), hal ini mereka

${ }_{13}$ Islam Moderat Menebar Islam Rahmatan Lil 'Alamin, Jakarta Timur, Pustaka Ikadi. 2012. h. 146. teladani dari dosen-dosen yang memiliki latar belakang murni pesantren.

Perpaduan kurikulum, yang dimaksud perpaduan kurikulum adalah, materi yang diajarkan di Ma'had 'Aly memadukan antara ushul fiqh, fiqh, dan tasawuf. Ushul fiqh merupakan metode yang digunakan oleh para juris Islam dalam memahami al-Qur'an dan Hadis, dengan ushul fiqh mereka dapat memahami maksud dari teks-teks otoritas Islam tertinnggi tersebut. Ini yang coba ditanamkan oleh Ma'had 'Aly kepada para santri, tujuannya adalah agar mereka dapat menelusuri dari mana dan bagaimana para ulama' bisa memutuskan hukum wajib, sunnah, mubah, haram, dan makruh akan suatu kasus. Ini membuktikan bahwa perhatian Ma'had 'Aly terhadap ushul fiqh sangatlah besar. Jadi mereka mempelajari ushul fiqh bukan sekedar ingin mengetahuinya melainkan juga untuk diterapkan.

Perpaduan model belajar dan kegiatan. Sebagai lembaga yang memiliki cita-cita besar mencetak kader ulama' yang dapat berbicara banyak dalam bidang fiqh di dunia yang sudah semakin bebas seperti sekarang, tidak heran apabila para pengurus dan praktisi Ma'had 'Aly Sukorejo berusaha menyeimbangkan gaya belajar pesantren dengan gaya belajar sekolah atau perguruanperguruan tingi di luar pesantren. Ini bertjuan agar para santri tidak ketinggalan informasi tentang perkembangan dunia luar, dan juga supaya mereka dapat memahami karakter orang-orang yang tidak pernah mengenyam pendidikan pesantren. Sehingga para santri, apabila dihadapkan dengan mereka, tidak akan merasa minder dan ragu melainkan tetap percaya diri. Lebih jau dari itu, mereka akan lebih menghargai perbedaan pendapat. 


\section{Karakter Moderat Santri Ma'had 'Aly Situbodo.}

Dalam proses penanaman karakter di Ma'had 'Aly, ada beberapa ciri karakter moderat yang dijumpai pada diri para santri. Diantaranya adalah sikap toleransi beragama yang dituangkan dalam beberapa tulisan mereka, salah satunya adalah tulisan yang berkaitan dengan perayaan natal, mereka menulis bahwa menghadiri perayaan natal hukumnya boleh sepanjang tidak dirayakan di tempat-tempat yang dipenuhi dengan berhala ataupun simbol-simbol non muslim lainnya. Tulisan ini mereka ekspos di buletin bulanan Ma'had 'Aly tanwirul afkar atau di buku figh progresif.

Bahwa sikap toleransi beragama adalah salah satu dari ciri Islam moderat sesuai dengan apa yang dituliskan oleh Prof. Dr. Abu Yasid, beliau menjelaskan bahwa salah satu bentuk dari kemoderatan Islam adalah kebebasan beragama, dalam arti harus menghargai keberadaan agama lain sebagai sebuah keniscayaan bukan dalam dalam rangka membenarkan agama-agama tersebut.

Selain sikap toleransi beragama, menurut Prof. Dr. Abu Yasid, moderasi dalam dunia Islam juga memberikan kebabasan berfikir pada semua pemeluknya senyampang kebebasan tersebut masih dalam batas normal dan wajar, tidak menabrak begitu saja teks-teks agama.

Ciri karakter lain yang tertanam pada santri Ma'had 'Aly adalah kemampuan mereka memadukan dan mengawinkan antara akal dan teks, di santu sisi mereka menghormati teks sebagai firman Allah SWT, tapi disisi lain mereka juga menghargai kemampuan akal sebagai anugerah dari
Allah SWT. Ini sejalan dengan apa yang disampaikan oleh Kyai Afifuddin Muhajir, bahwa Ma'had 'Aly mampu memadukan antara shohihul manqul da shorihul ma'qul. Prof. Dr Abu Yasid menyebutnya dengan penggabungan nalar dan wahyu.

Kemampuan mamadukan teks dan akal, nalar dan wahyu secara proporsional akan menjadikan para santri Ma'had 'Aly lebih terbuka dan tidak terlalu rigid dalam memahami teks-teks kitab kuning, bagi mereka kitab kuning adalah produk akal manusia yang masih mungkin benar dan mungkin saja salah. Oleh karena itu, jangan terlalu kaku dalam memahami teks-teks tersebut apalagi menerimanya begitu saja.

Salah satu ciri dari karakter moderat adalah kemampuan memposisikan diri berada ditengah-tengah antara liberalisme muthlak dan kejumudan muthlak. Jika kelompok pertama terlalu melalaikan kesakralan al-Qur'an sehingga dengan mudahnya mereka menabrak dan menerobos nash-nash al-Quran, tidak peduli apakah nash tersebut samapai pada derajat qoth'I atau tidak. Sedangkan kelompok kedua terlalau mensakralkan teks-teks kitab kuning, bagi mereka apa yang tertuang dalam literatur kitab kuning tersebut adalah harga mati yang tidak boleh diotak atik lagi.

Dua sikap ekstrim di atas tidak akan pernah dijumpai pada santri-santri Ma'had 'Aly, bagi mereka al-Qur'an adalah suatu yang sangat sakral sehingga apa yang sudah menjadi keputusannya, apalagi bersifat qoth'i, sama sekali tidak boleh diintervensi. Akan tetapi, kitab-kitab tafsir ataupun kitabkitab fiqh bukanlah suatu yang sakral dalam artian masih memiliki kemungkinan benar 
dan salah karena itu semua adalah karya manusia.

Namun betapapun berharganya akal bagi mereka, bukan berarti menjadikan akal sebagai pengambil keputusan terakhir disaat keputusan akal tersebut bertabrakan dengan keputusan nash. Mereka tidak suka terhadap sikap keterbukaan tanpa batas dan ketertutupan tanpa batas, karena dua pandangan ini hanya akan menyebabkan seseorang terjerumus ke dalam dua kutub ekstrim yang saling berlawanan satu sama lain.

Dalam setiap keputusan hukum yang dilakukan oleh para santri Ma'had 'Aly, yang menjadi konsideran utama adalah dampak mashlahah dan mafsadah yang akan timbul dari keputusan tersebut. Dalam prakteknya, mereka selalu memadukan dua model istinbath sekaligus, yaitu istinbath secara qouliy dan manhajiy.

Model istinbath qouly, menurut Kyai Afifudin Muhajir dalam bukunya metodologi fiqh, adalah menggali hukum dari teks-teks kitab yang sudah ada. Oeleh karena itu, memutuskan hukum dengan metode qouly hanya bisa dilakukan apabila kasus yang dicari hukumnya memiliki perbandingan atau setidaknya mirip-mirip dengan apa yang dijumpai dalam kitab-kitab klasik, sehingga memutuskan hukum dengan model ini sangat tekstual dan teks argumentatif. Akan tetapi, ketika kasus yang akan diputuskan tersebut tidak memiliki persamaan atau padanan dalam kitab-kitab klasik, maka mereka akan baralih dari istinbath qouly menuju istinbath manhajiy. Istinbath model kedua ini dilakukan apabila kasus yang dihadapi sama sekali baru dan tidak pernah dijumpai pada zaman ulama' madzhab. Atau, dijumpai perbandingannya akan tetapi sangat tidak mungkin memutuskan hukum menggunakan hukum yang telah digunakan beberapa abad lalu itu, di era yang sudah semodern sekarang, karena hal itu terlalu naif dan berlebihan tampaknya.

Istinbath manhajiy lebih kepada kajian bagaimana hukum itu terbentuk, perangkat yang digunakan adalah perangkat ushul fiqh. Perangkat yang sering digunakan adalah kajian maslahah, istihsan, "urf dan kajian historisitas teks atau lebih dikenal dengan sebutan asbab an-nuzul. Namun, semua perangkat ushul figh ini akan menjadi tumpul apabila berhadapan dengan ayatayat qoth'i.

Nah, disinilah perbedaan Ma'had 'Aly dengan pesantren pada umumnya, jadi bagi para santri Ma'had 'Aly tidak semua larangan harus berkonsekwensi haram dan perintah harus berkonsekwensi wajib. Yang harus dilakukan ketika bertemu dengan ayatayat al-Qur'an yang mengandung larangan ataupun perintah harus dicari reason/illatnya (alasannya) terlebih dahulu. Jadi tidak ujukujuk haram dan wajib, tapi harus dicari dulu apa alasan larangan dan perintah tersebut, dan apakah larangan atau perintah itu tegas ataukah tidak.

Nalar manhajiy adalah upaya yang dilakukan oleh Ma'had 'Aly agar Islam dapat bicara banyak di era global ini, karena alQur'an dan Hadis tidak turun dalam ruang hampa. Sehingga penting kiranya untuk membumikan nilai-nilai yang terkandung dalam ayat-ayat suci tersebut dengan cara, dilakukan penyesuaian-penyesuain teks dan konteks, agar ayat-ayat dan hadis nabi tidak hanya menjadi bahan bacaan saja melainkan 
dapat diterapkan dengan sebaik-baiknya demi kemashlahatan umat Islam seluruhnya.

\section{PENUTUP}

Berdasarkan pembahasan diatas, penelitian ini dapat disimpulkan sebagai berikut: pertama, Terbentuknya karakter moderat pada santri Ma'had 'Aly bukanlah suatu yang niscaya dan ada begitu saja, melainkan melalui beberapa prose dan pendekatan. Dari hasil observasi dan penelitian yang dilakukan penulis, setidaknya ada dua pendekatan yang dilakukan di lembaga unggulan pesantren Salafiyah Syafi'iah Sukorejo ini. Dua pendekatan tersebut adalah pengintegrasian pembelajaran dan pengintegrasian kegiatan dan materi yang diajarkan. Dalam prakteknya, pengintegrasian pembelajaran yang dilakukan Ma'had 'Aly adalah dua model yaitu, pertama, dengan cara memberi teladanan (modeling) pada para santri. Hal ini dilakukan dengan cara memadukan dosen yang murni lulusan pesantren dengan dosen yang memiliki latar belakang pendidikan umum. Kedua, pengkondisian lingkungan Ma'had 'Aly yang dirancang untuk menciptakan iklim keilmuan yang berbeda dengan lembaga lainnya di pesantren Salafiah Syafi'iah Sukorejo, lebih jauh dari itu, Ma'had 'Aly juga menanamkan budaya kritis yang notabnenya adalah salah satu ciri karakter moderat.

Selanjutnya adalah pengintegrasian dalam kegiatan sehari-hari atau materi, pengintegrasian ini dilakukan dengan memadukan tiga materi sejakaligus, yaitu fiqh, ushul fiqh, dan tasawuf, karena melalui perpaduan tiga materi ini seseorang bisa memiliki karakter moderat.
Karakter moderat yang berhasil tertanam pada santri Ma'had 'Aly sekurangkurangnya adalah sebagai berikut, toleransi, kemampuan menyeimbangkan anatara nalar dan wahyu (shohihul manqul dan shorihul ma'qul), menyeimbangkan antara bermadzhab secara qouliy (memutus persoalan dengan menggunakan teks fiqh) dan bermadzhab secara manhajiy (memutus persoalan dengan kaidah fiqh dan ushul fiqh).

Rekomendasi dan sasarannya adalah: Bagi pesantren-pesantren di Indonesia terutama yang menamakan dirinya sebagai pesantren salaf, diharapakan lebih memperhatikan peran ushul fiqh dalam setiap keputusan hukumnya. Jadi, ushul fiqh tidak hanya dipelajari sabegai ilmu murni sebagaimana ilmu-ilmu lain, melainkan harus disadari bahawa ushul fiqh adalah seubuah metode penggalian hukum yang harus tetap dilestarikan dan diterapkan.

Tujuannya adalah agar para lulusannya lebih terbuka menghadapi masalah-masalah sosial, sehingga tidak mudah menharamharamkan atau menghalal-halalkan setiap praktek sosial ataupun individu yang dijumpainya. Perhatian lebih yang diberikan pada ushul figh harus diseimbangkan dengan materi tasawuf, diharapkan agar para santri tidak menggunakan teory ushul fiqh secara bebas.

Disamping itu, kementerian agama sebagai instansi pemerintah yang konsen mengurusi sektor bidang keagamaan diharapkan lebih mewaspadai munculnya aliran-aliran keagamaan yang mengancam ideologi, seperti kaum fundamentalis dan liberalis. Hal ini dapat dilakukan dengan cara mulai menanamkan karakter muderat pada 
pemuda-pemuda penerus bangsa, khususnya yang ada di pesantren. Peneliti berharap, hasil penelitian ini dapat menjadi subangsih pemikiran bagaimana cara menanamkan karakter moderat pada para santri, yang kemudian untuk dimaklumatkan pada pesantren-pesantren di seluruh Indonesia.

\section{UCAPAN TERIMA KASIH}

Artikel ini merupakan hasil penelitian penulis yang dibiayai Puslitbang Pendidikan Agama dan Keagamaan, oleh karena itu penulis menyampaikan terima kasih kepada Kepala Puslitbang Pendidikan Agama dan Keagamaan Badan Litbang dan Diklat Kementerian Agama yang telah memberikan kesempatan kepada penulis untuk melakukan penelitian ini di Ma'ahad Aly Situbondo. Terima kasih juga penulis sampaikan kepada pimpinan Ma'had Aly Sukorejo Situbondo, para dosen, Mahasantri yang telah membantu memberikan sejumlah data-data dan informasi selama dalam penelitian. Kepada redaksi Jurnal Edukasi penulis juga sampaikan terimaksih atas dimuatnya artikel ini.

\section{DAFTAR PUSTAKA}

Ismail, Achmad Satori dkk, (2012): Islam Moderat Menebar Islam Rahmatan Lil 'Alamin, Jakarta timur, pustaka ikadi.
Satori, Ahmad dkk, (2012): Islam Moderat Menebar Islam Rahmatan Lil 'Alamin, Jakarta, Pustaka Ikadi, cet II

Satori, Ahmad dkk. (2012): Islam Moderat Menebar Islam Rahmatan Lil 'Alamin, Jakarta Timur, Pustaka Ikadi.

Departemen Pendidikan Nasional, Kamus Bahasa Indonesia, (Jakarta: Balai Pustaka, 2007),

Doni Koesoema, Pendidikan Karakter,

http://www.nugarislurus.com/2015/03/ kh-luthfi-bashori-alwi-10-kiatmenghadapi-jil-jaringan-Islam-liberal. html\#axzz3pT5LNdhA

Koentjaraningrat, (1981): Metode-Metode Penelitian Masyarakat, Jakarta, Gramedia Pustaka Utama.

Moleong, Lexy J. (2002): Metodologi Penelitian Kualitatif, Cet. 13. Bandung, Remaja Rosdakarya.

Rais, M. Amin (1987): Cakrawala Islam, Bandung, Mizan, Cet. 1.

Bahtiar, Wardi. (1987): Metodologi Penelitian Ilmu Dakwah, Jakarta, Logos Wacana Ilmu.

Zubaedi, (2013): Desain Pendidikan Karakter. Jakarta, Kencana Prenada Media Group. H. Mahmud, 2006. Model-Model Kegiatan di Pesantren. Ciputat: Media Nusantara.

Qodir, Zuly. (2010): Islam Liberal, Yogyakarta, LkiS, cet I 